\title{
Relationship among perceived stress, anxiety, depression and craniocervical pain in nursing professionals under stress at work
}

\author{
Relação entre o estresse percebido, ansiedade, \\ depressão e a dor craniocervical em profissionais \\ de enfermagem sob estresse no trabalho
}

\section{Daniela Pozzebon, Chaiane Facco Piccin, Ana Maria Toniolo da Silva, Eliane Castilhos Rodrigues Corrêa*}

Universidade Federal de Santa Maria (UFSM), Santa Maria, RS, Brazil

\begin{abstract}
Introduction: The appearance and evolution of some clinical pain conditions may be influenced by stress and other psychosocial factors. Face, head and cervical muscles may increase their activity and tension in the presence of stress, leading to craniocervicomandibular pain in individuals exposed to stress. Objective: To assess the relationship among perceived stress, anxiety, depression and craniocervicomandibular pain in nursing professionals under stress at work. Materials and Methods: Forty-three women under stress at work, according to the Job Stress Scale (JSS), were assessed by the Perceived Stress Scale (PSS), the Hospital Anxiety and Depression Scale (HADS), pressure pain threshold, measured by algometry, and muscle sensitivity to hand palpation of the masticatory and cervical muscles. Results: A low moderate level of perceived stress was found in $62.79 \%$ of the sample, anxiety in $11.63 \%$ and depression in $9.30 \%$. The psychosocial scales correlated with each other. No correlation was found between pressure pain threshold and perceived stress, anxiety and depression. The level of pain to hand palpation correlated with the perceived stress scores. Conclusion:
\end{abstract}

*DP: MSc, e-mail: danypozze@hotmail.com CFP: MSc, e-mail: chaiane.ufsm@gmail.com AMTS: PhD, e-mail: amariatoniolo@gmail.com ECRC: PhD, e-mail: eliftrs@yahoo.com.br 
Pressure pain threshold was not influenced by the psychosocial factors assessed. Pain intensity to hand palpation, however, was higher as the perception of stress increased.

Keywords: Anxiety. Depression. Psychological stress. Pain measurement.

\section{Resumo}

Introdução: $O$ aparecimento e evolução de algumas condições clínicas de dor podem ser influenciados pelo estresse e outros fatores psicossociais. A musculatura da face, cabeça e cervical podem aumentar sua atividade e tensão na presença do estresse, podendo provocar dor craniocervicomandibular nos indivíduos a ele expostos. Objetivo: Avaliar a relação entre estresse percebido, ansiedade, depressão e a dor craniocervicomandibular em profissionais da enfermagem sob estresse no trabalho. Materiais e Métodos: 43 mulheres sob estresse no trabalho, de acordo com a Escala de Estresse no Trabalho (JSS), foram avaliadas pelas Escalas de Estresse Percebido (PSS), Escala Hospitalar de Ansiedade e Depressão (HADS), limiar de dor à pressão, por algometria, e a sensibilidade muscular por palpação manual dos músculos mastigatórios e cervicais. Resultados: Nível moderado baixo de estresse percebido foi encontrado em 62,79\% da amostra, ansiedade em 11,63\% e depressão em 9,30\%. As escalas psicossociais se correlacionaram entre si. Não houve correlação entre limiar de dor à pressão e estresse percebido, ansiedade e depressão. $O$ nível de dor à palpação manual se correlacionou com os escores de estresse percebido. Conclusão: Os fatores psicossociais avaliados não influenciaram o limiar de dor à pressão. Entretanto, a intensidade da dor à palpação manual foi mais alta à medida que aumentou a percepção do estresse.

Palavras-chave: Ansiedade. Depressão. Estresse psicológico. Medição da dor.

\section{Introduction}

The appearance and evolution of some clinical pain conditions may be influenced by stress and other psychosocial factors (1). Moreover, psychosocial factors have been pointed out as a predictor of disability in several musculoskeletal conditions (2).

Stress may increase pain sensitivity and influence pain processing in the central nervous system, thus altering its dimension (3). Psychosocial factors have also been mentioned as contributors to individual differences in pain processing (4). As such, the perception of a painful condition may be strongly altered, according to the value assigned to the situation experienced (5).

Some studies have correlated psychosocial factors and the presence of musculoskeletal pain in workers exposed to stress at work $(6,7)$. In those instances, depression and anxiety symptoms produced by stress might result in muscular hyperactivity and, as a result, lead to muscle pain (8).

Stress at work is the stress caused or exacerbated by work (9). It is defined as negative emotional and physical responses occurring when work requirements do not correspond to the workers' abilities, resources or needs (10).
Coping strategies employed by individuals when exposed to stressing conditions include physiological and behavioral responses (11). Thus, high levels of occupational stress may cause anxiety, depression, and physical disease, among others (12).

Nursing is a profession identified as a highly stressful occupation $(13,14)$. Thus, it may represent a predisposing factor for the appearance of occupational diseases linked to stress.

Considering that face, head and cervical muscles may increase their activity and tension in the presence of stress, it is believed that exposure to stress at work, and its consequent psychological changes (anxiety, depression), may cause craniocervicomandibular pain in individuals exposed to stress. Painful symptoms in this segment may cause oral myofunctional changes, thus affecting important stomatognathic functions such as mastication and swallowing (15). However, studies related to the presence of pain specifically in the craniocervical area and its relationship with stress or psychosocial factors were not found.

Based on the abovementioned, investigating the occurrence of physical changes in this population, and their association with psychosocial factors is 
warranted, aiming to avoid the onset of chronic conditions that may lead to decreased productive capacity and/or disability and, as a consequence, work leave. Therefore, this study aimed to assess the existence of a relationship between perceived stress, anxiety, depression and craniocervicomandibular pain in nursing professionals under stress at work.

\section{Materials and methods}

The presente study is part of the "Craniocervicomandibular System: assessment and multimodal therapeutic intervention" project, approved by the Research Ethics Committee of the Federal University of Santa Maria (UFSM), under protocol number 33665714.0.0000.5346, according to resolution $466 / 2012$ of the National Health Council.

The research was carried out with a group of female nursing professionals from a hospital institution in the town of Santa Maria/RS, recruited by means of oral divulgation of this research. Those interested in taking part in the study completed an anamnesis form and the Job Stress Scale (JSS).

The anamnesis form included data related to socio-demographic (age, marital status, number of children) and occupational (function, length of time working in the current function, other employment bond) characterization, and additional data that made it possible the selection of volunteers according to the inclusion and exclusion criteria of this study.

In order to be included in the research, the participants had to be women, nursing professionals (nursing technicians and nurses), aged between 20 and 50 years old, to be at least for three months performing the same function, at the same institution, as well as being exposed to stress at work, according to the JSS. In addition, they should agree on the procedures to be performed, which were previously explained, and sign a Free and Informed Consent Term.

The exclusion criteria were: signs of neuropsychomotor involvement, to be under the effect of painkiller, anti-inflammatory, myorelaxant or anxiolytic drugs, previous cervical spine and/or facial surgery, previous treatment for orofacial or cervical spine pain in the past six months, and previous treatment for cancerous disease in the last five years.

The JSS scale assesses stress based on three dimensions: psychological demands, control and social support. In this study, the JSS scale was adapted, and the social support dimension was not assessed. Workers exposed to a combination of high demands and low control were deemed as the group of higher exposure to stress at work; those exposed to high demands, but with high control, or exposed to low demands and low control, were deemed as the group of intermediate exposition to stress at work, and the group with high control and low demands was classified as not exposed to stress at work (16).

Of the 53 professionals screened, three were excluded from the research because they did not fit into the established age group, and seven of them for not being exposed to stress at work according to JSS.

This research was conducted in the Orofacial Laboratory of Motricity of the Federal University of Santa Maria, including 43 women aged between 20 and 50 years old. All participants were informed on the procedures to be performed.

Once selected, the volunteers were assessed by means of specific scales for perception of stress and for the presence of anxiety and depression. In addition, pressure and hand palpation pain threshold was assessed.

The Perceived Stress Scale (PSS) was used for assessing the participants' perception of stress. The result is a value between 0 and 40 , where the highest scores denote the highest stress perceived (17). In order to be analyzed, the scores for this scale were divided into stratified quartiles: 0-10 (low level), 11-20 (moderate level), 21-30 (high moderate level), and 31- 40 (high level).

Aiming to assess the presence of anxiety and depression, the Hospital Anxiety and Depression Scale (HADS) (18) was used. That scale comprises seven items designed to assess anxiety (HADS-A), and seven items to assess depression (HADS-D). The results for each scale may range from 0 to 21 points, where: 0 - 7 points denote absence of anxiety/depression, 7 to 9 points, probable anxiety/depression, and more than 10 points, presence of anxiety/depression (18).

The verification of pain sensitivity to palpation was referred by the volunteers as absent, mild, moderate or severe (according to a numerical scale ranging from zero to three) through palpation of muscles and structures, according to the Research Diagnostic Criteria for Temporomandibular Disorders (RDC/ TMD) (19). Palpation was performed bilaterally, with the examiners' digital pulps of index fingers and middle fingers. The pressure employed was $1 \mathrm{Kg}$. The following sites were palpated: temporal (posterior, 
middle and anterior bundles), masseter (upper, middle and lower parts), posterior mandibular region, submandibular region, lateral pole and posterior ATM ligament. Palpations were always performed by the same examiner, who was previously trained and prepared to apply the systematized RDC/TMD protocol. Still, for calibration of the hand pressure applied by the examiner, an algometer was used, enabling the visualization of the intensity of pressure applied (20).

Cervical muscles sensitivity was not assessed through hand palpation, as these sites are not included in the RDC/TMD protocol.

Pressure pain threshold (PPT) was assessed with a pressure algometer - Force Dial ${ }^{\mathrm{TM}}$ Dynamometer FDK/FDN (Wagner Instruments). The algometer was positioned perpendicular to the site assessed, while the examiner's hand supported the participant head. The volunteers were told to verbally express the moment when pressure caused a painful sensation (21), as the pressure increased over the analyzed area. PPT was verified in the same sites assessed by hand palpation. Additionally, the cervical muscles PPT (anterior scalene, sternocleidomastoid, suboccipital, and upper and middle trapezius), were bilaterally verified. Every spot was pressed twice, with a three-minute interval between each repetition and the mean values were calculated (22). The minimum pressure value considered for registration was $0.5 \mathrm{~kg} / \mathrm{cm}^{2}$, and $4 \mathrm{~kg} / \mathrm{cm}^{2}$ was the maximum pressure applied by the algometer, in case the volunteer did not report pain when assessing these muscles.

Statistical Analysis

The Spearman Correlation Coefficient was used to verify the correlation among the variables studied. P-value $<0.05$ was considered as statistically significant.

The statistical analysis was performed using STATISTICA 9.1 software.

\section{Results}

The sample comprised 43 women with mean age of $35.33 \pm 6.78$ years old, exposed to stress at work. Among them, 97.67\% showed intermediate level and $2.33 \%$ high level of exposure to stress according to JSS. The sample comprised nursing technicians
(74.42\%) and nurses (25.58\%), and the average length of time performing the function in the same institution was $5.35 \pm 4.46$ years. From the totality, $60.47 \%$ were married and $65.12 \%$ had children. Most of them practiced neither physical activity (82.72\%) nor leisure activities (70.07\%).

The results obtained through JSS, PSS e HADS (HADS-A e HADS-D) scales are showed in Table 1.

Table 1 - Distribution of the sample regarding the classification in the Perceived Stress Scale (PSS) and Hospital Anxiety and Depression Scale (HADS)

\begin{tabular}{lccc}
\hline & SCORE & $\mathbf{n}$ & $\%$ \\
\hline PSS & $0-10$ & 3 & 6.98 \\
& $11-20$ & 27 & 62.79 \\
& $21-30$ & 12 & 27.91 \\
& $31-40$ & 1 & 2.33 \\
HAD-A & Normal & 25 & 58.14 \\
& Probable & 13 & 30.23 \\
& Presence & 5 & 11.63 \\
HAD-D & Normal & 35 & 81.40 \\
& Probable & 4 & 9.30 \\
& Presence & 4 & 9.30 \\
\hline
\end{tabular}

Note: Legend: PSS = Perceived Stress Scale; HADS-A = Hospital Anxiety and Depression Scale (anxiety); HADS-D = Hospital Anxiety and Depression Scale (depression)

The mean values obtained in the evaluations of the pain threshold to pressure and hand palpation are presented in Table 2 .

Table 2 - Mean values obtained in the evaluations of the pain threshold to pressure and hand palpation (To be continued)

\begin{tabular}{lcc}
\hline Muscle & $\begin{array}{c}\text { Pressure pain threshold } \\
\left(\mathbf{c m}^{\mathbf{2}}\right)\end{array}$ & Hand palpation \\
\hline & $\begin{array}{c}\text { Mean } \pm \text { Standard } \\
\text { deviation }\end{array}$ & $\begin{array}{c}\text { Mean } \pm \text { Standard } \\
\text { deviation }\end{array}$ \\
AT & $2.49 \pm 0.79$ & $0.47 \pm 0.85$ \\
MT & $2.74 \pm 0.97$ & $0.58 \pm 0.90$
\end{tabular}


Table 2 - Mean values obtained in the evaluations of the pain threshold to pressure and hand palpation (Conclusion)

\begin{tabular}{lcc}
\hline Muscle & $\begin{array}{c}\text { Pressure pain threshold } \\
\left(\mathbf{c m}^{2}\right)\end{array}$ & Hand palpation \\
\hline PT & $3.06 \pm 0.91$ & $0 ; 86 \pm 1.04$ \\
UM & $1.97 \pm 0.58$ & $0.57 \pm 0.82$ \\
MM & $1.72 \pm 0.52$ & $1.26 \pm 1.10$ \\
LM & $1.73 \pm 0.49$ & $1.30 \pm 1.11$ \\
PMR & $1.24 \pm 0.49$ & $0.88 \pm 1.09$ \\
SMR & $1.67 \pm 0.65$ & $0.23 \pm 0.60$ \\
SCM & $1.00 \pm 0.44$ & - \\
SC & $2.08 \pm 0.70$ & - \\
UT & $2.92 \pm 0.81$ & - \\
MT & $3.20 \pm 0.84$ & - \\
SO & $2.06 \pm 0.82$ & - \\
\hline
\end{tabular}

Note: Legend: $\mathrm{AT}$ = anterior temporal; $\mathrm{MT}=$ middle temporal; $\mathrm{PT}=$ posterior temporal; UM = upper masseter; MM: = middle masseter; $\mathrm{LM}=$ lower masseter; PMR = posteromandibular region; SMR = submandibular region; SCM = sternocleidomastoid; $S \mathrm{~S}=$ scalene; $\mathrm{UT}=$ upper trapezius; $\mathrm{MT}=$ middle trapezius; $\mathrm{SO}=$ suboccipital

The results of correlations between anxiety, depression, perceived stress, pain threshold and hand palpation are as shown in Table 3.

Table 3 - Correlations between perceived stress, anxiety, depression, hand palpation and pressure pain threshold

(To be continued)

\begin{tabular}{lcc}
\hline & $\mathbf{r}$ & $\mathbf{p}$ \\
\hline Perceived stress & & \\
Anxiety & 0.579 & $0.000^{\star}$ \\
Depression & 0.601 & $0.000^{\star}$ \\
Hand palpation & 0.430 & $0.004^{\star}$ \\
$\begin{array}{l}\text { Pressure pain } \\
\text { threshold }\end{array}$ & 0.137 & 0.381 \\
Anxiety & & \\
Depression & 0.618 & $0.000^{\star}$ \\
Hand palpation & 0.213 & 0.171
\end{tabular}

Table 3 - Correlations between perceived stress, anxiety, depression, hand palpation and pressure pain threshold

(Conclusion)

\begin{tabular}{lcc}
\hline & $\mathbf{r}$ & $\mathbf{p}$ \\
\hline $\begin{array}{l}\text { Pressure pain } \\
\text { threshold } \\
\text { Depression } \\
\text { Hand palpation }\end{array}$ & 0.087 & 0.577 \\
$\begin{array}{l}\text { Pressure pain } \\
\text { threshold }\end{array}$ & 0.243 & 0.116 \\
$\begin{array}{l}\text { Hand palpation } \\
\text { Pressure pain } \\
\text { threshold }\end{array}$ & 0.132 & 0.398 \\
\hline
\end{tabular}

Note: r: Spearman Correlation Coefficient

*: statistically significant difference $(p<0.05)$

\section{Discussion}

The present study selected professional women from nursing area aiming to assess the relationship between craniocervicomandibular pain and anxiety, depression and perceived stress. This choice was based on the fact that nursing is deemed to be a highly stressing profession (7). It was decided to limit the research to women, as nursing is a profession where there is a prevalence of the female gender $(6,12)$. Still, it was taken into account that disorders such as depression and anxiety are more common in women (1).

The majority of individuals in this study showed intermediate levels of stress, as well as other studies using the same assessment tool as this research, and other instruments conceived to assess nurses $(10,12)$.

The presence of high level of occupational stress in only one participant in the study may be explained by the workload hours. Most of these individuals have only one employment bond. As detected previously, multiemployment and excessive workload hours are sources of stress among workers $(23,24)$. In the intermediate level, however, stress at work was found among the individuals in this sample. The study concluded that the more experience and identification with the workplace, the lesser will be the negative impact of stress (25). In the present research, the bond with the institution was less than five years for the majority of workers. 
Most women in this sample do not practice physical activity regularly (83.72\%) or leisure activities (70.07\%). The absence of such activities hinders the dissipation of physical and emotional tensions stemming from the workplace. The beneficial effect of physical activity on anxiety and depression was demonstrated (26). Furthermore, strategies for adaptation to stress can be promoted through the practice of relaxation exercises (11).

This research results have revealed a low moderate level of perception of stress. This can be related to the intermediate level of exposure to occupational stress referred by most participants (97.67\%). Also, the perception of stress may vary depending on the moment of assessment, e.g., the individual's working days. Higher levels of perceived stress are found when the individual works on the weekends (27). Although the participants worked on weekends, no assessment was performed on these days.

In this study, $11.63 \%$ of professionals showed anxiety, and $9.30 \%$ showed depression, verified through HADS. In a similar way, $16 \%$ and $6.2 \%$ anxiety and depression, respectively, were found in clinical nurses in a hospital (28). By using the HADS clinical cutoff, where individuals are rated as with or without anxiety and/ or depression, $41.86 \%$ of sample show anxiety, and $18.60 \%$ showed depression. Using the same clinical cutoff in this same scale, a study found $31.3 \%$ of individuals with anxiety, and $24.2 \%$ with depression (29). It can be noted a high percentage of workers in the nursing area presenting psychological changes. Many occupational factors may be linked to the psychological changes in the nursing staff: work in shifts (30) and the lack of positive conditions in the workplace (28).

Correlations were found among perceived stress, anxiety and depression, suggesting that the workers who had higher scores in one of the scales had also higher scores in all other scales. As a result, if one of these psychological changes gets worse, it may impact the others. High scores of anxiety, verified through an instrument called State-Trait Anxiety Inventory, was the factor more strongly correlated to perceived stress in workers in a footwear industry (31). Among students in the last semester of nursing school, it was verified that the stress scores have followed proportionally depression scores (32). A significant and positive correlation was verified between the scores of Beck Anxiety Inventory and Beck Depression Inventory in a study carried out with nursing professionals (33).
In the present study, the values obtained by assessing PPT for masseter muscle (UM $=1.97 \mathrm{~kg} / \mathrm{cm}^{2}$, $\mathrm{MM}=1.72 \mathrm{~kg} / \mathrm{cm}^{2}$ and $\mathrm{LM}=1.73 \mathrm{~kg} / \mathrm{cm}^{2}$ ) and temporal muscle $\left(\mathrm{AT}=2.49 \mathrm{~kg} / \mathrm{cm}^{2}, \mathrm{MT}=2.74 \mathrm{~kg} / \mathrm{cm}^{2}\right.$ and $\mathrm{PT}=3.06 \mathrm{~kg} / \mathrm{cm}^{2}$ ) were similar to those determined, like the cutting point for asymptomatic patients, and patients with signs and symptoms of TMD $\left(1.5 \mathrm{~kg} / \mathrm{cm}^{2}\right.$ for the masseter, $2.47 \mathrm{~kg} / \mathrm{cm}^{2}$ for the anterior tempo$\mathrm{ral}, 2.75 \mathrm{~kg} / \mathrm{cm}^{2}$ for the middle temporal, and $2.77 \mathrm{~kg} /$ $\mathrm{cm}^{2}$ for the posterior temporal muscles) (34). Research found mean values of $1.41 \mathrm{~kg} / \mathrm{cm}^{2}$ and $1.67 \mathrm{~kg} / \mathrm{cm}^{2}$ for masseter and temporal muscles, assessed bilaterally, in healthy individuals (35). PPT of $2.7 \mathrm{~kg} / \mathrm{cm}^{2}$ on trapezius muscle was found when assessing individuals without myofascial dysfunctions (36), similar to the value found $\left(2.92 \mathrm{~kg} / \mathrm{cm}^{2}\right)$ in the present research.

As expected, among the exams performed by hand palpation and pressure algometry, there was a significant negative association, i.e., lower levels of pressure pain threshold denote higher levels of pain.

Pressure pain threshold does not correlate with any psychosocial variables studied. The values obtained through hand palpation do not correlate with anxiety and depression. However, hand palpation of the assessed muscles correlated with the level of perceived stress. People have different fatigue thresholds due to stress and their responses may vary, and this becomes a highly relevant factor for the appearance of illnesses or not (12). It is believed that the same might happen with other psychological disturbances, such as anxiety and depression, and may be expressed by the individual in different ways.

The lack of statistical association between the values obtained through algometry and the psychosocial factors assessed can be attributed to the fact that the values found through the participant's algometry were similar to those found in studies assessing healthy and asymptomatic individuals (34-36). Although it has been shown that the algometry ability to symptomatic from asymptomatic individuals was comparable to hand palpation (37), a few studies combining hand palpation and algometry have been performed. Pressure algometry, although regarded as an easy-toapply technique and superior to the hand palpation technique, has some limitations: the patient response, pain localization and magnitude, muscle contraction level and the rate of pressure applied (38). Research performed showed that masticatory muscles PPT, both in symptomatic and asymptomatic individuals, was lower during a stressing event (academic exam), 
showing a relationship between stress and anxiety levels and muscular sensitivity level (21). Perhaps, different results could be found if the sample was assessed at other times. Healthy individuals assessed consecutively and after six months, showed different pressure pain thresholds in each assessment (35).

Accordingly, it is believed that this study sample has shown more psychological than physical repercussions related to occupational stress. Also, physical symptoms may be present in other sites in the body, not in the craniocervical region, as assessed in this study. Significant correlations between back pain and psychosocial factors have been found.

Of note, the present study had some constraints, such as the reduced sample size and the fact that it was constituted mainly by professionals working for a short time in the institution, and with intermediate levels of occupational stress. Moreover, just one assessment tool was used for each psychosocial variable.

Subsequent research is recommended that assesses the overall effect of stress on pain in different body sites as well as in individuals with high levels of exposure to stress at work.

This study made it possible to find psychological changes caused by exposure to stress at work. Symptoms of anxiety and depression may not only negatively affect an individual well-being, but also generate a decrease in labor productivity among these individuals. The chronicity of exposure to stress at work added to psychological manifestations may be expressed in the long term under the form of pain, thus generating additional personal and labor damage.

Therefore, it becomes evident the need for the application of awareness measures and stress control, thus preventing future damage to health.

\section{Conclusion}

The nursing professionals assessed in the present study showed a low moderate level of perception of stress, presenting anxiety and depression in about $10 \%$ of volunteers. Perceived stress, anxiety and depression showed a correlation with each other, but had no influence on pressure pain threshold. However, with the increase of stress perception, pain intensity to hand palpation increased, indicating that many of these professionals may have subclinical symptoms of craniocervicomandibular pain, which only become evident when this region is palpated.

\section{References}

1. Fillingim RB, Ohrbach R, Greenspan JD, Knott C, Dubner R, Bair E, et al. Potential psychosocial risk factors for chronic TMD: descriptive data and empirically identified domains from the OPPERA case-control study. J Pain. 2011; 12(11):T46-T60.

2. Christensen J, Knardahl S. Work and neck pain: a prospective study of psychological, social, and mechanical risk factors. Pain. 2010; 151(1):162-73.

3. Cathcart S, Winefield AH, Lushington K, Rolan P. Stress and tension-type headache mechanisms. Cephalalgia. 2010; 30(10):1250-67.

4. Schreiber KL, Martel MO, Shnol H, Shaffer JR, Greco C, Viray N, et al. Persistent pain in postmastectomy patients: comparison of psychophysical, medical, surgical, and psychosocial characteristics between patients with and without pain. Pain. 2013; 154(5):660-8.

5. Pinheiro RC, Uchida RR, Mathias LADST, Perez MV, Cordeiro Q. Prevalence of depressive and anxiety symptoms in patients with chronic pain. J Bras Psiquiatr. 2014; 63(3):213-9.

6. Habibi E, Taheri MR, Hasanzadeh A. Relationship between mental workload and musculoskeletal disorders among Alzahra Hospital nurses. Iran J Nurs Midwifery Res. 2015; 20(1):1-6.

7. Magnago TSBS, Lisboa MTL, Griep RH, Kirchhof ALC, Guido LA. Aspectos psicossociais do trabalho e distúrbio musculoesquelético em trabalhadores de enfermagem. Rev Lat Am Enfermagem. 2010; 18(3):429-35.

8. Kindler S, Samietz S, Houshmand M, Grabe HJ, Bernhardt 0 , Biffar R, et al. Depressive and anxiety symptoms as risk factors for temporomandibular joint pain: a prospective cohort study in the general population. J Pain. 2012; 13(12):1188-97.

9. Al-Makhaita HM, Sabra AA, Hafez AS. Predictors of work-related stress among nurses working in primary and secondary health care levels in Dammam, Eastern Saudi Arabia. J Family Community Med. 2014; 21(2):79-84.

10. Najimi A, Goudarzi AM, Sharifirad G. Causes of job stress in nurses: A cross-sectional study. Iran J Nurs Midwifery Res. 2012; 17(4):301-5. 
11. Mehrabi T, Azadi F, Pahlavanzadeh S, Meghdadi, N. The effect of yoga on coping strategies among intensive care unit nurses. Iran J Nurs Midwifery Res. 2012; 17 (6):421-4.

12. Dalri RCMB, Silva LA, Mendes AMOC, Robazzi MLCC. Nurses' workload and its relation with physiological stress reactions. Nurses' workload and its relation with physiological stress reactions. Rev Lat Am Enfermagem. 2014; 22(6):959-65.

13. Sharma P, Davey A, Davey S, Shukla A, Shrivastava K, Bansal, R. Occupational stress among staff nurses: Controlling the risk to health. Indian J Occup Environ Med. 2014; 18(2):52-6.

14. Yu J, Ren X, Wang Q He L, Wang J, Jin Y, et al. The role of social support on occupational stress among hospital nurses. Int J Clin Exp Med. 2014; 7(9):3000-4.

15. Weber P, Corrêa ECR, Bolzan GP, Ferreira FS, Soares JC, Silva AMT. Mastigação e deglutição em mulheres jovens com desordem temporomandibular. CoDAS. 2013; 25(4):375-80.

16. Schmidt DRC, Dantas RAS, Marziale MHP, Laus AM. Estresse ocupacional entre profissionais de enfermagem do bloco cirúrgico. Texto Contexto Enferm. 2009; 18(2):330-7.

17. Cohen S, Karmack T, Mermelsteinm R. A global measure of perceived stress. J Health Soc Behav. 1983; 24(4):385-96.

18. Botega NJ, Bio MR, Zomignani MA, Garcia C Jr, Pereira WA. Mood disorders among inpatients in ambulatory and validation of the anxiety and depression scale HAD. Rev Saude Publica. 1995; 29(5):355-63.

19. Dworkin SF, LeResche L. Research diagnostic criteria for temporomandibular disorders: review, criteria, examinations and specifications, critique. J Craniomandib Disord. 1992; 6(4):301-55.

20. Conti PCR, Silva RS, Araujo CRP, Rosseti LMN, Yassuda S, Silva ROFD, et al. Effect of experimental chewing on masticatory muscle pain onset. J Appl Oral Sci. $2011 ; 19(1): 34-40$.

21. Vedolin GM, Lobato VV, Conti PCR, Lauris JRP. The impact of stress and anxiety on the pressure pain threshold of myofascial pain patients. J Oral Rehabil. 2009; 36(5):313-21.
22. Gomes MB, Guimarães FC, Guimarães SMR, Neves ACC. Limiar de dor à pressão em pacientes com cefaléia tensional e disfunção temporomandibular. Braz Dent Sci. 2010; 9(4):84-91.

23. Guido LA, Linch GFC, Pithan LO, Umann J. Estresse, coping e estado de saúde entre enfermeiros hospitalares. Rev Esc Enferm USP. 2011; 45(6):1434-9.

24. Liu WW, Pan FC, Wen PC, Chen SJ, Lin SH. Job Stressors and Coping Mechanisms among Emergency Department Nurses in the Armed Force Hospitals of Taiwan. Int J Human Soc Scis. 2010; 4(7):124-31.

25. Cavalheiro AM, Moura Junior DF, Lopes AC. Estresse de enfermeiros com atuação em unidade de terapia intensiva. Rev Lat Am Enfermagem. 2008; 16(1): 29-35.

26. Lindwall $M$, Gerber $M$, Jonsdottir IH, Börjesson $M$, Ahlborg Jr G. The relationships of change in physical activity with change in depression, anxiety, and burnout: A longitudinal study of Swedish healthcare workers. Health Psychol. 2014; 33(11): 1309-18.

27. Purcell SR, Kutash M, Cobb S. The relationship between nurses' stress and nurse staffing factors in a hospital setting. J Nurs Manag. 2011; 19(6):714-20.

28. Taghinejad H, Suhrabi Z, Kikhavani S, Jaafarpour M, Azadi A. Occupational mental health: A study of workrelated mental health among clinical nurses. J Clin Diagn Res. 2014; 8(9):1-3.

29. Schmidt DRC, Dantas RAS, Marziale MH. Anxiety and depression among nursing professionals who work in surgical units. Rev Esc Enferm USP. 2011; 45(2):487-93.

30. Flo E, Pallesen S, Magerøy N, Moen BE, Grønli J, Nordhus IH, et al. Shift work disorder in nurses-assessment, prevalence and related health problems. PloS One. 2012; 7(4):e33981.

31. Medeiros Neto CF, Almeida GA, Ramos BC, Costa SKP, Silva HPAD, Sousa MBC. Análise da percepção da fadiga, estresse e ansiedade em trabalhadores de uma indústria de calçados. J Bras Psiquiatr. 2012; 61(3):133-8.

32. Moreira DP, Furegato ARF. Estresse e depressão entre alunos do último período de dois cursos de enfermagem. Rev Lat Am Enfermagem. 2013; 21(spe):155-62. 
33. Gomes RK, Oliveira VB. Depressão, ansiedade e suporte social em profissionais de enfermagem. Bol Psicol. 2013; 63 (138):23-33.

34. Silva RS, Conto PCR, Lauris JRP, Silva RO, Pegoraro LF. Pressure pain threshold in the detection of mastigatory myofascial pain: an algometer-based study. J Orofac Pain. 2005; 19(4):318-24.

35. Fredriksson L, Alstergren P, Kopp S. Absolute and relative facial pressure-pain thresholds in healthy individuals. J Pain. 2000; 14(2):98-104.

36. Fischer AA. Pressure algometry over normal muscles. Standart values, validity and reproducibility of pressure threshold. Pain. 1987; 30:115-26.

37. Gomes MB, Guimarães JP, Guimarães FC, Neves ACC. Palpation and pressure pain threshold: reliability and validity in patients with temporomandibular disorders. Cranio. 2008; 26(3):202-10.

38. Jensen R, Rasmussen BK, Pedersen B, Lous I, Olesen J. Cephalic muscle tenderness and pressure pain threshold in a general population. Pain. 1992; 48(2):197-203.

Received: 07/06/2014

Recebido: 06/07/2014

Approved: $10 / 08 / 2014$

Aprovado: 08/10/2014 
